\title{
Summer mistral at the exit of the Rhône valley
}

\author{
By P. DROBINSKI ${ }^{1 *}$, S. BASTIN ${ }^{1}$, V. GUENARD ${ }^{2}$, J.-L. CACCIA ${ }^{2}$, A. M. DABAS ${ }^{3}$, P. DELVILLE ${ }^{4}$, \\ A. PROTAT ${ }^{5}$, O. REITEBUCH ${ }^{6}$ and C. WERNER ${ }^{6}$ \\ ${ }^{1}$ Institut Pierre Simon Laplace/Service d'Aéronomie, Paris, France \\ ${ }^{2}$ Laboratoire de Sondages Electromagnétiques de l'Environnement Terrestre, La Garde, France \\ ${ }^{3}$ Centre National de Recherches Météorologiques, Météo-France, France \\ ${ }^{4}$ Division Technique/Insitut National des Sciences de l'Univers, Meudon, France \\ ${ }^{5}$ Institut Pierre Simon Laplace/Centre d'Étude des Environnements Terrestre et Plantaires, Vélizy, France \\ ${ }^{6}$ Deutsche Zentrum für Luft- und Raumfahrt, Weissling, Germany
}

(Received 26 March 2004; revised 8 September 2004)

\section{SUMMARY}

The paper examines the three-dimensional structure and dynamics of the mistral at the Rhône valley exit on 28 June 2001. The mistral refers to a severe wind that develops along the Rhône valley in southern France. This summer mistral event was documented in the framework of the ESCOMPTE field experiment. The dynamical processes driving the circulation of the mistral in the Rhône valley and particularly wake formation and planetary boundary layer (PBL) inhomogeneity at the scale of Rhône valley delta are investigated. Several important data sources are used (airborne Doppler lidar, radiosondes and surface stations) as well as non-hydrostatic mesoscale simulations.

This paper analyses experimentally, numerically and theoretically the mechanism of wake formation. It shows that the flow impinging on the Alpine range and the Massif Central becomes supercritical all along the ridge line, including the Rhône valley and continues to accelerate in the lee regions until a hydraulic jump occurs. It leads to the formation of wakes behind and close to the mountain peaks. Compared to the Massif Central wake, the origin of the western Alps wake is rather complicated. In this study, the observations and simulations suggest a combined wall separation/gravity wave breaking mechanism to explain the western Alps wake. Indeed, it is shown that in addition to the flow descending the western Alps slopes and experiencing a strong hydraulic jump, the point where the mistral flow separates from the eastern flank of the Rhône valley located at about $44^{\circ} \mathrm{N}$ is associated with a 'flank-shock' which is an oblique hydraulic jump (i.e. the downstream Froude number is supercritical).

Wake formation in the lee of the Alps and the Massif Central causes large inhomogeneity of the PBL with differences between land and sea. In the Massif Central and western Alps wakes, the continental PBL is deeper $(1.8 \mathrm{~km})$ than in the mistral flow $(1 \mathrm{~km})$, which is consistent with a subcritical regime associated with enhanced turbulent mixing. The supercritical air flow, descending the Massif Central and Alps slopes and transitioning to subcritical flow, increases the near-surface air temperature due to the föhn effect. Over the Mediterranean, the surface heat fluxes are slightly negative (between -50 and $0 \mathrm{~W} \mathrm{~m}^{-2}$ ) and the main source of PBL turbulence is mechanical (wind shear). The PBL depth within the mistral flow does not vary over land $(1 \mathrm{~km})$, whereas the absence of convection but also of strong winds prevent PBL development over the sea in the wakes of the Massif Central and the Alps (PBL depth of about $0.5 \mathrm{~km}$ ).

KeYwords: Hydraulic jump Mountain wake Planetary boundary layer Valley flow

\section{INTRODUCTION}

The mistral refers to a severe wind that develops along the Rhône valley and influences the coast of south-eastern France and the western Mediterranean climate (Fig. 1). Mistral brings clear skies, but wind gusts can cause severe damage to farm plantations, hazardous conditions for aeronautics and ship navigation (Mayençon 1982), and increased forest fire risks (Wrathall 1985) in the region. On a more regional scale, the mistral is frequently observed to extend as far as a few hundred kilometres from the coast (Jansá 1987) and is one of the primary causes of storms over the Mediterranean (Trigo et al. 1999; Campins et al. 2000). It brings cold and dry continental air over the warm western Mediterranean, generating intense air-sea heat exchanges (Flamant 2003) and sea surface cooling (Millot 1979), inducing the formation of the western Mediterranean deep water that moves into the Atlantic Ocean (Rhein 1995; Schott et al. 1996).

\footnotetext{
${ }^{*}$ Corresponding author: Institut Pierre Simon Laplace/Service d'Aéronomie, Paris, France. e-mail: philippe.drobinski@aero.jussieu.fr

(c) Royal Meteorological Society, 2005.
} 
It also affects the dilution of the pollutant species released by industrial plants located along the Rhône valley and near Marseille.

The development of the mistral is preconditioned by cyclogenesis over the Gulf of Genoa and the passage of a trough through France. When the synoptic northerly flow impinges on the Alpine range, it splits and is deflected west by the Coriolis force as well as the pressure build-up on the northern edge of the range. As the flow experiences channelling in the Rhône valley, separating the French Alps (highest elevation $4807 \mathrm{~m}$ ) to the east from the Massif Central (highest elevation $1885 \mathrm{~m}$ ) to the west by a gap $200 \mathrm{~km}$ long and $60 \mathrm{~km}$ wide (Fig. 1), it is substantially accelerated, giving birth to the mistral. The mistral occurs all year long but exhibits a seasonal variability either in speed and direction, or in its spatial distribution (Mayençon 1982; Orieux and Pouget 1984; Guénard et al. 2005). It shares its occurrence with land-sea breezes (Bastin et al. 2005; Bastin and Drobinski 2005).

The mistral mechanism was first described as cold air funnelling through the Rhône valley, or fall wind (Galzi 1952; Gerbier and Berenger 1961; Bordeuil et al. 1973; Mayençon 1982; Wrathall 1985). Pettré (1982) described the mistral dynamics by the two-dimensional reduced-gravity shallow-water theory, in which the flow under consideration is bounded by a free surface. Pettré's approach was recently used to explain long-range pollution transport and mixing in the mistral flow (Corsmeier et al. 2005).

However, two-dimensional reduced-gravity shallow-water theory is partly questionable at the exit of the Rhône valley since, at its southern part (Avignon-Marseille, see Fig. 1), it is no more a valley but a delta without sidewalls. The dynamics of the mistral is therefore more complex. Indeed, as the mistral exits the Rhône valley, it forms a jet, faster than adjacent air streams which form wakes. Its western and eastern boundaries are partly defined by hydraulic jumps and gravity wave breaking over the Massif Central which separates the mistral from the tramontane, and the Alps, respectively (Jiang et al. 2003). The tramontane blowing through the Garonne gap between the Massif Central and the Pyrénées (Fig. 1) is an example of a 'tramontana' wind, and is considered to be the companion of the mistral since they have the same synoptic origin and often blow simultaneously (Georgelin and Richard 1996; Drobinski et al. 2001a).

The wakes trailing downstream from the Massif Central and the Alps are associated with numerous elongated filaments of anomalous potential vorticity (PV banners) (Aebischer and Schär 1998; Schär et al. 2003). The generation of these flow features is the result of dissipation in flow-splitting/separation and/or gravity wave breaking events (Schär and Smith 1993; Schär and Durran 1997; Aebischer and Schär 1998). The mistral jet forms a 'primary' PV banner which emerges at the south-western tip of the Alps, whereas 'secondary' PV banners appear to the lee of the Po valley (Schär et al. 2003; Flamant et al. 2004). Aebischer and Schär (1998) showed that the development of the lee cyclone is not overly affected by the secondary PV banners, the mistral thus being the primary source of cyclogenesis in the western Mediterranean (see also Trigo et al. 1999; Campins et al. 2000).

However, the fine-scale structure (kilometre scale) of the mistral at the exit of the Rhône valley has never been investigated, because the ability to observe natural threedimensional (3D) atmospheric airflow patterns such as jets and wakes has progressed slowly. The fine-scale complexity of the flow structure is due to the fact that the mistral is composed of the predominantly northerly jet formed in the Rhône valley, the northwesterly and northerly downslope jets generated by the Massif Central and the Alps, and the wakes trailing south of the Massif Central and the Alps (see Fig. 15 in Jiang et al. 2003). The nature of the wakes in the lee of the Massif Central and the Alps, and of 

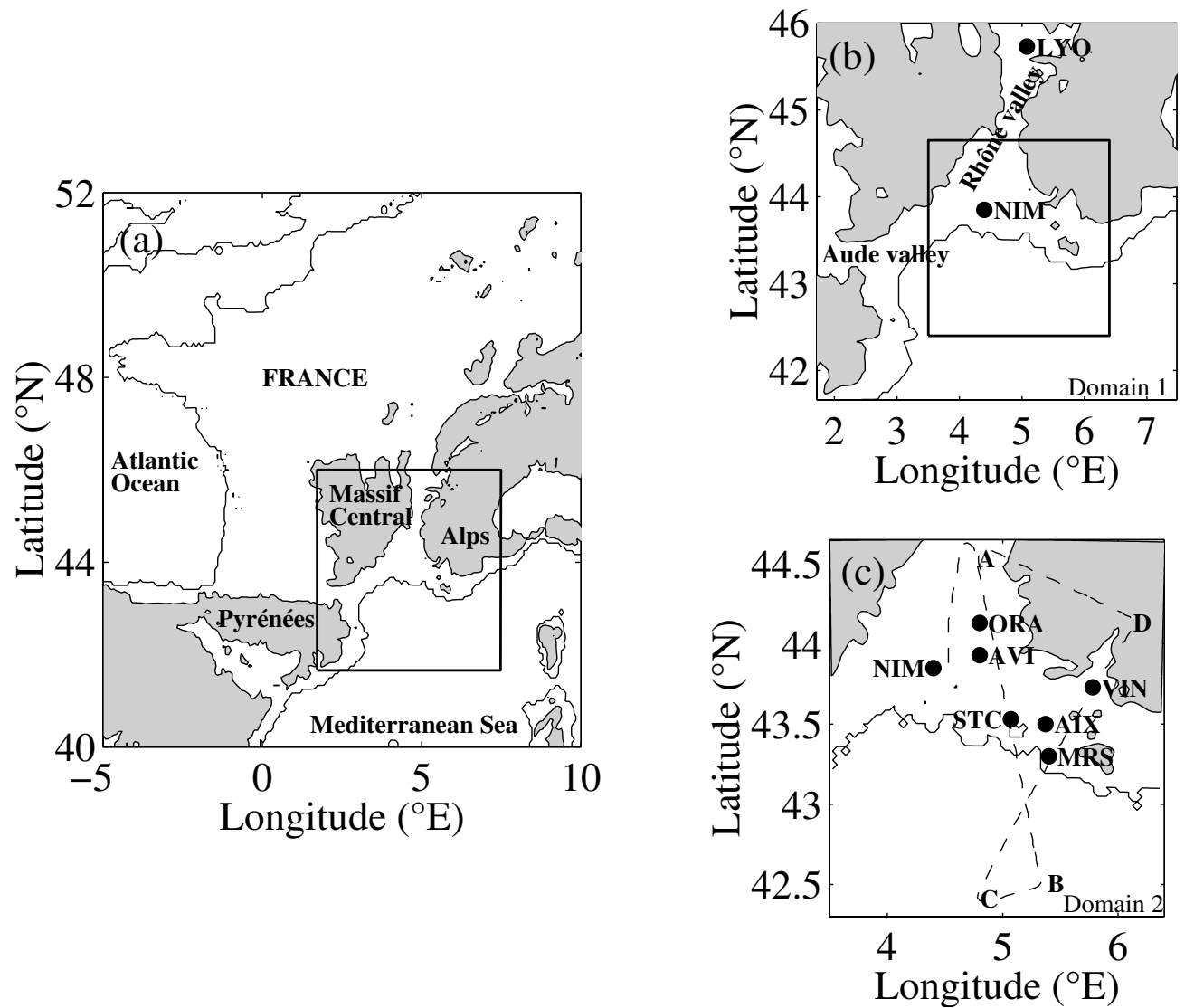

Figure 1. (a) Map of France with the topography shaded in grey when higher than $500 \mathrm{~m}$ above sea level. The rectangle displays the large domain (hereafter called domain 1) of the MM5 simulations. (b) Domain 1 of the MM5 simulation with its nested smaller domain (hereafter called domain 2) in the rectangle. The acronyms NIM and LYO stand for the city names Nîmes and Lyon, respectively. (c) Domain 2 of the MM5 simulation. The dashed line corresponds to the flight track of the DLR Falcon 20 carrying the Doppler lidar WIND on 28 June 2001 (the letters A, B, C and D indicate the track corners). The flight altitude is $6.5 \mathrm{~km}$ and the aircraft speed is about $170 \mathrm{~m} \mathrm{~s}^{-1}$. The acronyms AIX, AVI, MRS, ORA, STC and VIN correspond to Aix en Provence, Avignon, Marseille, Orange, Saint Chamas and Vinon, respectively.

the jet forming between the two massifs, and their impact on the planetary boundary layer structure, are of crucial importance for short-range weather forecasting, which is a critical issue in predicting the threat to ships, small aircraft and commercial jets, and the risk of forest fires. Recently, the MAP (Mesoscale Alpine Programme) field experiment (Bougeault et al. 2001), among other objectives, aimed at documenting and studying the dynamics of the secondary PV banners associated with wakes and jets exiting the numerous gaps transecting the Alpine ridge (Schär et al. 2003; Flamant et al. 2004). The documentation of the mistral-induced primary PV banner received comparatively much less attention. Jiang et al. (2003), relying on the few observations collected during MAP in southern France, proposed mechanisms to explain the lateral boundaries of the mistral and concluded with the multiscale dynamics of the mistral.

During the ESCOMPTE (Expérience sur Site pour COntraindre les Modèles de Pollution atmosphériques et de Transport d'Emissions) field experiment, conducted in June and July 2001 in southern France (Cros et al. 2005) (Fig. 1), several summer mistral 
events were documented (Corsmeier et al. 2005; Guénard et al. 2005; Caccia et al. 2005). During the 28 June 2001 mistral case, the French-German airborne Doppler lidar WIND (Wind INfrared Doppler, Werner et al. 2001) was flown and mapped in 3D the mistral wind at the exit of the Rhône valley (jets and wakes) and the associated planetary boundary layer (PBL) structure (depth). These measurements were complemented with thermodynamical measurements by radiosondes and surface stations, and mesoscale numerical simulations using the Penn State-National Center for Atmospheric Research MM5 model (Grell et al. 1995). Specifically, this paper analyses:

- the dynamic processes driving the small-scale structure of the mistral flow at the exit of the Rhône valley, and particularly the hydraulics that explains the wakes to the south of the western Alps and the Massif Central.

- the impact of the wake/jet structure of the flow at the Rhône valley exit on the PBL horizontal inhomogeneity.

After the introduction in section 1, the instrument set-up and the numerical model used in this study are described in section 2 . In section 3, the meteorological environment leading to the mistral episode is analysed, as well as the upstream conditions and the funnelling mechanism in the Rhône valley. In section 4, the structure of the mistral flow, and the generated jet and wakes, at the Rhône valley exit are discussed. In section 5, the impact of the jet/wake structure on the PBL structure is addressed. Section 6 concludes and suggests future work and prospects.

\section{MEASUREMENTS AND MODEL}

(a) Observations

During the ESCOMPTE experiment, a wide range of instruments was deployed around Marseille, leading to a dense network of observations available from Doppler and ozone lidars, wind profilers, sodars, radiosondes and meteorological surface stations (see the details in Cros et al. 2004). The aim of this experiment was to study the role of land/sea-breeze circulations in air pollution transport at local to regional scale (e.g. Bastin et al. 2005; Bastin and Drobinski 2005). The 28 June 2001 mistral case was not an intensive observing period and could not benefit from the whole instrumental set-up (ground-based observation network and research aircrafts). We thus only use the available measurements from the airborne Doppler lidar WIND, the operational radiosondes and synoptic meteorological stations of Météo-France, which were in operation this day. The complementarity of the data provided by these various instruments is an essential aspect of this study. The locations of the operational wind measurement sites used in this study are shown in Fig. 1.

(i) Radiosondes and in-situ surface stations. On 28 June 2001, only operational radiosondes were released, every twelve hours from Nîmes and Lyon. At the surface, the operational meteorological surface-station network gave access to the surface thermodynamical fields (wind, temperature, humidity, pressure). In addition to this network, a few stations providing radiative flux measurements were deployed for the campaign.

(ii) The airborne Doppler lidar WIND. The French-German airborne Doppler lidar WIND was operated on the 28 June 2001 mistral case between 1016 and 1041 UTC. The lidar is operated at $10.6 \mu \mathrm{m}$ in the infrared spectral region and was on board the Falcon 20 of the Deutsche Zentrum für Luft- und Raumfahrt (DLR) (Werner et al. 2001). It flew along the tracks shown in Fig. 1(c) at an altitude of $6.5 \mathrm{~km}$ with an aircraft ground 
speed of around $170 \mathrm{~m} \mathrm{~s}^{-1}$. At $10.6 \mu \mathrm{m}$ wavelength, the lidar signals are extremely sensitive to micron-sized aerosols which are excellent tracers of the dynamics in the troposphere, therefore making WIND a relevant tool for the study of PBL dynamics in complex terrain (e.g. Reitebuch et al. 2003; Bastin et al. 2005). The Doppler lidar WIND provides radial wind velocity measurements along the line-of-sight (LOS) of the transmitted laser beam. The wind profile is obtained by conically scanning the LOS around the vertical axis with a fixed angle of $30^{\circ}$ from nadir. The profile of the 3D wind vector was calculated from the profiles of the LOS wind speeds using a velocityazimuthal display (VAD) technique (Caya and Zawadzki 1992). A full scan revolution of the LOS takes $20 \mathrm{~s}$, leading to a horizontal resolution of about $3.4 \mathrm{~km}$ between vertical profiles of the wind vector. The vertical resolution of the wind profiles is $250 \mathrm{~m}$ and the accuracy of the horizontal wind velocity is better than $1 \mathrm{~m} \mathrm{~s}^{-1}$. A 3D-variational analysis called MANDOP (Multiple ANalytical DOPpler, Scialom and Lemaitre 1990) was also applied to the high-resolution horizontal wind profiles derived from WIND to provide a $3 \mathrm{D}$ wind field on a regular horizontal grid bounded by the flight tracks. The MANDOP wind field is variationally adjusted to the regularly-spaced vertical profiles of horizontal wind retrieved from WIND with the VAD technique. The anelastic approximation of the air-mass continuity equation is also introduced in the minimization procedure, as well as the condition that the vertical wind component is nil at ground-level or following complex terrain. The following cost function is therefore minimized in the least-squares sense:

$$
\begin{aligned}
F= & \sum_{\text {WIND data }}\left\{\left(u_{\mathrm{ANA}}-u_{\mathrm{WIND}}\right)^{2}+\left(v_{\mathrm{ANA}}-v_{\mathrm{WIND}}\right)^{2}\right\} \\
& +\lambda_{1} \sum_{\text {3D DOMAIN }}\left(\nabla \cdot \rho \mathbf{V}_{\mathrm{ANA}}\right)^{2}+\lambda_{2} \sum_{\text {GROUND }}\left(w_{\mathrm{ANA}}\right)^{2}
\end{aligned}
$$

where $\mathbf{V}_{\mathrm{ANA}}=\left(u_{\mathrm{ANA}}, v_{\mathrm{ANA}}, w_{\mathrm{ANA}}\right)$ is the MANDOP wind vector to be retrieved, $\left(u_{\text {WIND }}, v_{\text {WIND }}\right)$ are the two horizontal wind components retrieved using the VAD technique, and $\lambda_{1}$ and $\lambda_{2}$ are weighting factors. Owing to the sampling strategy carried out by the airborne wind lidar, the scales resolved by the MANDOP analysis in this configuration are about $15-20 \mathrm{~km}$ horizontally and $250 \mathrm{~m}$ vertically. Because of the fast aircraft speed, the evolution of the wind field during the flight is neglected and the retrieved wind field is considered as an instantaneous snapshot of the true wind field.

The lidar reflectivity allows the retrieval of the PBL top. Indeed, the PBL top is characterized by large gradients of mean quantities, such as the relative humidity and aerosol content, to which the backscattered lidar signal is highly sensitive. Lidar profiles always exhibit a local discontinuity (or transition zone) between the PBL and the troposphere above. In the following, we define the local PBL top height as the base of the transition zone (i.e. the top of the mixed layer) using a gradient algorithm.

\section{(b) Model}

The numerical simulations presented in this study have been conducted with the Penn State-National Center for Atmospheric Research MM5 model, version 3.6 (Grell et al. 1995). The model solves the non-hydrostatic equations of motion in terrainfollowing sigma coordinates. Two interactively nested model domains are used, the horizontal mesh size being $9 \mathrm{~km}$ and $3 \mathrm{~km}$, respectively. Domains 1 (coarse domain) and 2 (fine domain) are centred at $43.7^{\circ} \mathrm{N}, 4.6^{\circ} \mathrm{E}$ and cover an area of $450 \mathrm{~km} \times 450 \mathrm{~km}$ and $228 \mathrm{~km} \times 246 \mathrm{~km}$, respectively (see Fig. 1). Domain 1 covers the Rhône valley, the western Alps and the Massif Central. Domain 2 covers the Rhône valley delta. 
The model orography of the two domains was interpolated from terrain data with $30^{\prime \prime}$ resolution. It is filtered by a two-pass smoother-desmoother (Guo and Chen 1994) in order to remove two-grid-interval waves that would induce numerical noise. Information on land use was obtained from United States Geological Survey (USGS) data with the same horizontal resolution as for orography. In the vertical, 43 unevenly spaced fullsigma levels are used, corresponding to 42 half-sigma levels where most of the variables are computed. The lowermost half-sigma level $(\sigma=0.999)$ is about $12 \mathrm{~m}$ above ground. The vertical distance between the model levels is about $50 \mathrm{~m}$ close to the ground and increases up to $1000 \mathrm{~m}$ near the upper boundary which is located at $100 \mathrm{hPa}$.

A complete set of physics parametrizations is used. Cloud microphysics is treated with a sophisticated scheme having prognostic equations for cloud water, cloud ice, cloud ice particle number concentration, rain, snow and graupel (Reisner et al. 1998). The Grell cumulus parametrization (Grell 1993) is used in model domain 1. In model domain 2, a cumulus parametrization is not needed because convection is resolved explicitly at such high resolution. The radiation scheme accounts for the interaction with moisture and clouds (Grell et al. 1995; Mlawer et al. 1997). The PBL is parametrized using the Hong and Pan scheme (Hong and Pan 1996). It is an efficient scheme based on Troen and Mahrt representation of countergradient term and eddy viscosity profile in the well mixed PBL, and is suitable for high resolution in PBL. The PBL top is diagnosed using Eq. (8) of Hong and Pan (1996).

The initial and boundary conditions are taken from the operational ECMWF (European Centre for Medium-Range Weather Forecasts) analyses. These analysis data are available every six hours on a $0.25^{\circ} \times 0.25^{\circ}$ latitude-longitude grid. Since the interpolation routine of the MM5 modeling system needs pressure-level data, the standard-levelpressure version of the ECMWF data is used. The initialization date is 27 June 2001 at 1200 UTC and the simulation ends on 29 June 2001 at 0600 UTC.

In the following, MM5 simulations are validated and used to provide the $3 \mathrm{D}$ environment necessary for the interpretation of the measurements.

\section{CASE DESCRIPTION}

\section{(a) Synoptic environment}

The 28 June 2001 mistral event features a zonal flow over the Atlantic Ocean resulting from an anticyclone over Spain and a low-pressure system over the northern Atlantic (Fig. 2(a)). A surface low zone (1010 hPa) may be noticeable over the northern Mediterranean. The zonal flow drives convective thunderstorms crossing the northern part of France during the night on 27-28 June 2001. After the passage of the cold front, a surface low is generated $(1008 \mathrm{hPa})$ in the wake of the Alps ridge (Fig. 2(b)), marking the onset of the mistral wind due to the Genoa cyclogenesis process. On 28 June 2001 in the morning, a high-pressure zone (1020 hPa) coming from Spain is moving eastward and strengthens north-westerly winds over the Mediterranean. The Mediterranean cyclone $(1010 \mathrm{hPa})$ also moves eastward and is centred over Corsica at 1200 UTC (Fig. 2(c)). During the afternoon, the high-pressure zone moves to the north-east and its centre is located over France, deflecting the Atlantic air masses toward the North Sea. On 29 June 2001 (Fig. 2(d)), the Genoa cyclone weakens and moves to the south-east over southern Italy $(1016 \mathrm{hPa})$, while high pressure increases over the Balearic Isles (1022 hPa). This results in the cessation of the mistral wind. Routine rawinsondes launched at Nîmes indicate that the passage of the short wave is accompanied by cool air masses (not shown). The air mass gets warmer and drier after the return of the anticyclonic weather conditions indicating that mistral conditions are 

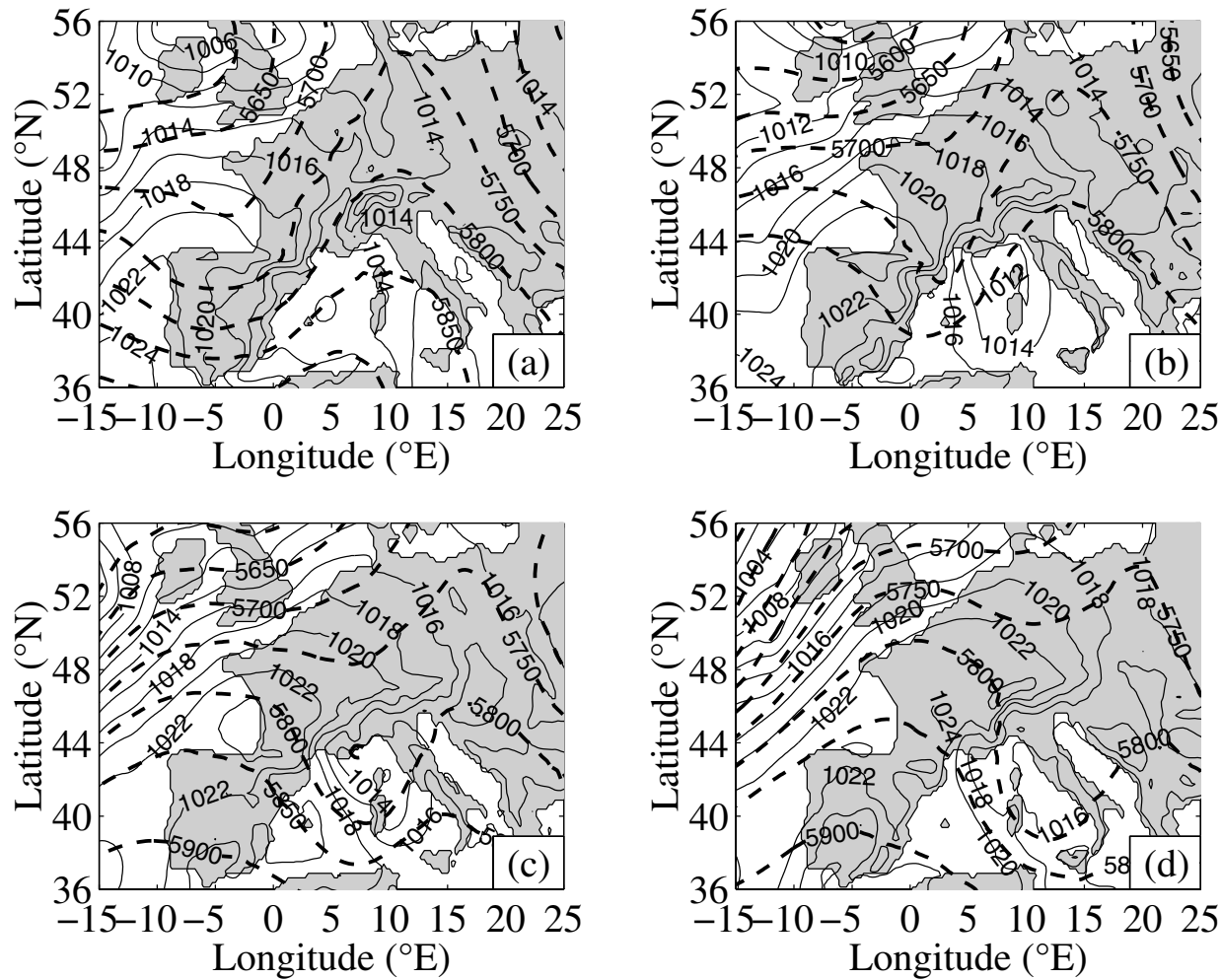

Figure 2. Synoptic situation in 12-hourly intervals on (a) 27 June 2001 at 1200 UTC, (b) 28 June 2001 at 0000 UTC and (c) 1200 UTC, and (d) on 29 June 2001 at 0000 UTC, from ECMWF analyses. The mean-sealevel pressure and $500 \mathrm{hPa}$ geopotential heights are shown with solid (contour interval $2 \mathrm{hPa}$ ) and thick dashed (50 m) lines, respectively.

not present any more. During the mistral event, surface winds observed over land have not exceeded $10 \mathrm{~m} \mathrm{~s}^{-1}$ and ECMWF wind analysis indicates stronger north-westerly winds over the sea reaching $20 \mathrm{~m} \mathrm{~s}^{-1}$.

The synoptic environment on 28 June 2001 is a basic situation for the triggering of the mistral wind. Wind intensity is weak due to weak gradient pressure forcing and the duration of the mistral wind is short (about one day). Those characteristics are in agreement with the climatology of mistral events during the warm season (Orieux and Pouget 1984).

\section{(b) Upstream conditions}

The radiosonde launched from Lyon on 28 June 2001 at 1200 UTC shows the synoptic north-westerly flow blowing above $3 \mathrm{~km}$ above sea-level (ASL) (Fig. 3(a) and (b)). Below the potential temperature inversion at $2.3 \mathrm{~km}$, a low-level jet blows at about $10 \mathrm{~m} \mathrm{~s}^{-1}$ from the north and is aligned with the Rhône valley axis, evidencing channelling in the valley. Between 2.3 and $3 \mathrm{~km}$ ASL, the wind direction veers to the north-east (Fig. 3(b)). The MM5 model fails in reproducing the temperature inversion and the slight wind direction shift between 2 and $3 \mathrm{~km}$ but is on average performing well (at most, $2 \mathrm{~m} \mathrm{~s}^{-1}$ difference in the wind speed, less than $20^{\circ}$ and $1 \mathrm{~K}$ differences on average for the wind direction and potential temperature, respectively). 


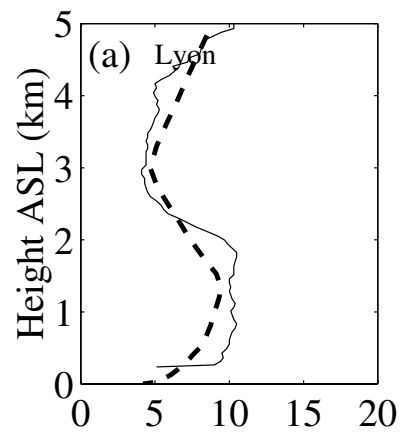

Wind speed $\left(\mathrm{m} \mathrm{s}^{-1}\right)$

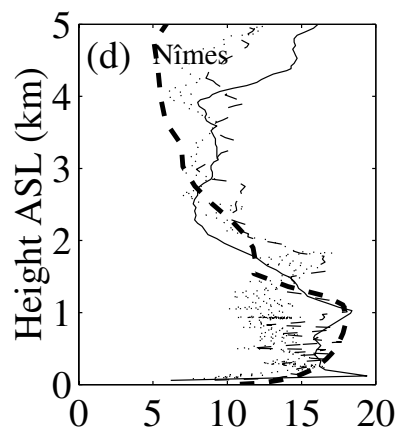

Wind speed $\left(\mathrm{m} \mathrm{s}^{-1}\right)$

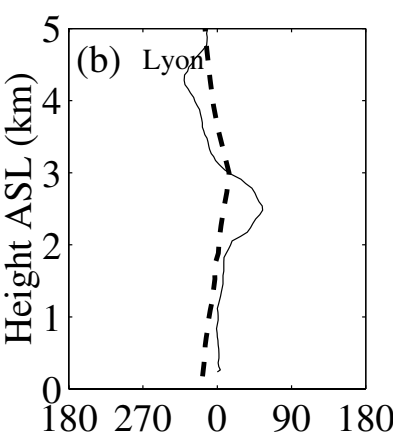

Wind direction $\left({ }^{\circ}\right)$

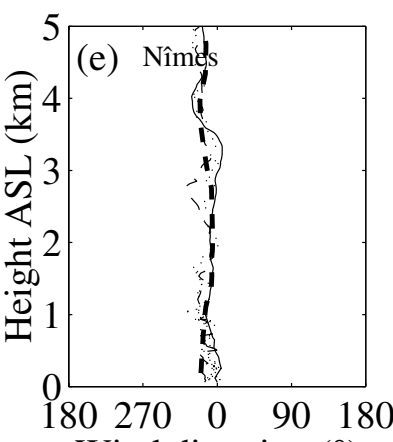

Wind direction $\left(^{\circ}\right)$
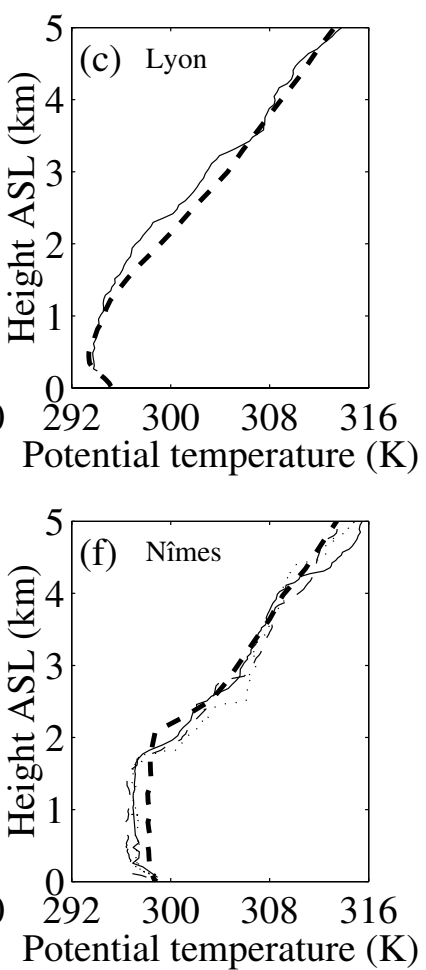

Figure 3. Vertical profiles of wind speed (a) and (d), wind direction (b) and (e) and potential temperature (c) and (f) over Lyon (first row) from the 1200 UTC sounding (solid line) and over Nîmes (second row) from the 1200 UTC sounding (solid line), the 0930 UTC Falcon ascent (dashed line) and the 1100 UTC Falcon 20 descent (dotted line) on 28 June 2001. The 1200 UTC simulated profiles at Lyon and at Nîmes are displayed with a thick dashed line.

The mistral jet blows within the PBL. The controlling parameters of upstream blocking are the normalized mountain height $N h / U$ and the cross-mountain Rossby number $R o=U / f L$ (ratio of the acceleration and the Coriolis force), where $U$ is the mean upstream wind, $N$ the Brunt-Väisälä frequency, $h$ the ridge height, $L$ the half-width of the mountain, and $f$ the Coriolis parameter (Pierrehumbert and Wyman 1985; Smolarkiewicz and Rotunno 1989). Smolarkiewicz and Rotunno (1989) noted that the structure of the orographically induced flow perturbations varies dramatically as a function of $N h / U$ : when $N h / U \simeq 1$, air parcels flow almost directly across the mountain and large amplitude gravity waves develops over the peak ('flowover'); when $N h / U \gg 1$, the gravity-wave response is drastically reduced as much of the air stream is diverted around the flanks of the mountain followed by lee vortices formation ('flowaround'). In the present case, $h=2.5 \mathrm{~km}, L=80 \mathrm{~km}$ (Sprenger and Schär 2001; Drobinski et al. 2003). The radiosonde from Lyon gives $N \simeq 8 \times 10^{-3} \mathrm{~s}^{-1}$ and $U \simeq 10 \mathrm{~m} \mathrm{~s}^{-1}$, which leads to $N h / U \simeq 2$ and $R o \simeq 1.3$ which predict blocking by the Alpine ridge, the Coriolis force limiting the upstream extent of the decelerated layer.

\section{(c) Channelling in the Rhône valley}

Figure 3 (d)-(f) displays the vertical profiles of wind speed and direction and potential temperature over Nîmes from the 1200 UTC radiosonde and from the 0930 UTC 
ascent and the 1100 UTC descent of the DLR Falcon 20 aircraft. It shows that the mistral characteristics are fairly persistent with time (even though the mistral strength increases from about $13 \mathrm{~m} \mathrm{~s}^{-1}$ at 0930 and 1100 UTC to about $16 \mathrm{~m} \mathrm{~s}^{-1}$ at 1200 UTC) and that above the mistral, winds are observed to be relatively constant in time in magnitude (d) and in direction (e). The vertical profiles of potential temperature (f) and relative humidity (not shown) indicate a multi-layer structure above the mistral (at $1.8 \mathrm{~km}$ ). Indeed, the flow between 1.8 and $2.8 \mathrm{~km}$ is observed to be moist, as well as the layer between 3 and $4.5 \mathrm{~km}$. A good agreement is found between the observations and the MM5 simulations (the MM5 model slightly overestimates the PBL depth which is $2.1 \mathrm{~km}$ in the simulation versus $1.8 \mathrm{~km}$ in the observations). Figure 3 illustrates the föhn-like characteristics of the mistral flow as its temperature increases by $3 \mathrm{~K}$ between Lyon at the Rhône valley entrance and Nîmes at the exit. In addition, the mistral flow experiences substantial acceleration by channelling, since its speed increases by about $6 \mathrm{~m} \mathrm{~s}^{-1}$ between Lyon (about $10 \mathrm{~m} \mathrm{~s}^{-1}$ ) and Nîmes (about $16 \mathrm{~m} \mathrm{~s}^{-1}$ ). The potential temperature inversion is found at $1.8 \mathrm{~km}$ at Nîmes (versus $2.3 \mathrm{~km}$ at Lyon).

This case is similar to the 27 November 1977 mistral case studied by Pettré (1982) who diagnosed a hydraulic jump occurring near Orange $\left(44.13^{\circ} \mathrm{N}\right), 40 \mathrm{~km}$ north of Nîmes (where the Rhône valley broadens, see Fig. 1), using the reduced-gravity shallowwater theory (see their Fig. 9). The flow regime depends on the upstream PBL depth $H$ and upstream Froude number $F r=U / \sqrt{g^{\prime} H}$ (the Froude number is the ratio between the velocity of the fluid and the velocity of the gravity wave at the base of the inversion layer), where $U$ is the upstream wind velocity, $g^{\prime}$ the reduced-gravity acceleration ( $g^{\prime}=g \Delta \theta / \theta$, where $g$ is the gravity acceleration, $\theta$ is the average potential temperature in the PBL and $\Delta \theta$ is the potential temperature difference at the inversion) (the upstream conditions, $U, H$ and $g^{\prime}$, are derived from the radiosonde launched from Lyon). A flow is called sub- (super-) critical when the local Froude number is lower (greater) than unity. When the flow transitions from a supercritical to a subcritical regime, a hydraulic jump occurs, characterized by a sharp wind speed deceleration and layer depth deepening (e.g. Drobinski et al. 2001b). The 27 November 1977 mistral case studied by Pettré (1982) was characterized by $H \simeq 2.4 \mathrm{~km}$ and $F r=0.61$. In our case, $H \simeq 2.3 \mathrm{~km}$ and $F r=0.58$, with $g^{\prime} \simeq 1.3 \times 10^{-1} \mathrm{~m} \mathrm{~s}^{-2}$ and $U \simeq 10 \mathrm{~m} \mathrm{~s}^{-1}$. Pettre (1982) found that the PBL depth after the jump (at Orange and Nîmes) was about $0.69 \mathrm{H}$, i.e. $1.7 \mathrm{~km}$, which is very close to the $1.8 \mathrm{~km}$ found at Nîmes in our case. With different upstream conditions ( $H=1.5 \mathrm{~km}$ and $F r=0.29)$, Corsmeier et al. (2005) also diagnosed a hydraulic jump occurring north of Nîmes $\left(43.85^{\circ} \mathrm{N}\right)$, using the reduced-gravity shallow-water theory. In this theory, the potential-temperature inversion plays the role of a rigid lid below which the mistral flow is embedded. This assumption of a rigid lid is never fully met since entrainment at the PBL top in valley flows has been found to play an important role, in combination with surface friction, in balancing the down-valley acceleration (e.g. Mass et al. 1995), and considerations of the strength of the stable layer capping the PBL are crucial with respect to the possible exchanges of energy between the lower and the upper layer (Eliassen and Palm 1960). The potential temperature difference in the inversion at Nîmes is about $3.2 \mathrm{~K}$, which is of the same magnitude as those found in Jackson and Steyn (1994), Liu et al. (2000), Drobinski et al. (2001a) and Flamant et al. (2002), who were successful in using the reduced-gravity shallow-water theory to compute a hydraulic analogy to gap and valley flows. It is however much less than the $8 \mathrm{~K}$ potential temperature difference in the inversion found by Corsmeier et al. (2005) during the 1 July 2001 mistral case. Figure 3 shows that the PBL is well mixed (nearly constant potential temperature in the PBL) probably due to enhanced dissipation in the expected jump (e.g. Drobinski et al. 2001b). 

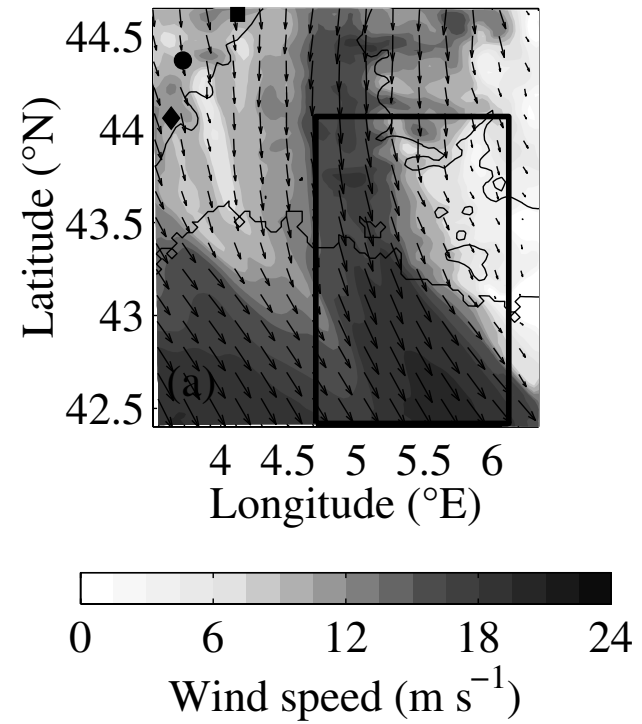
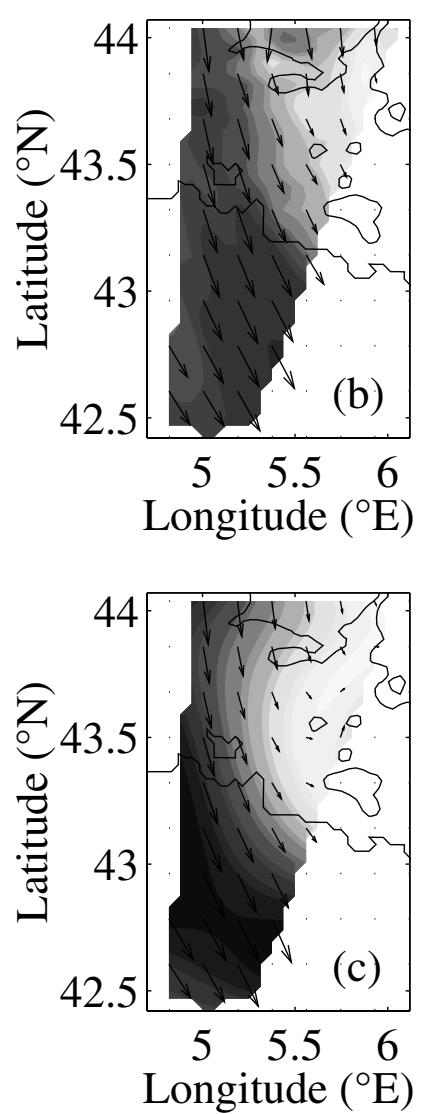

Figure 4. (a) Horizontal field of horizontal wind at $500 \mathrm{~m}$ AGL from MM5 simulations on 28 June 2001 at 1100 UTC. The rectangle indicates the region where the airborne Doppler lidar flew. The filled black circle, square and diamond indicates the location of Mont Mézenc, Mont Lozère and Mont Aigoual, respectively. (b) is the same as (a) but zoomed in on the region indicated by the rectangle. The MM5 simulations are interpolated on the grid used to analyse the WIND measurements retrieved using the MANDOP analysis. (c) is the same as (b) but for the observed wind field.

\section{JET STRUCTURE AND WAKE GENERATION AT THE RHÔNE VALLEY EXIT}

\section{(a) Flow description}

The two-dimensional reduced-gravity shallow-water theory may however be partly questionable at the exit of the Rhône valley since at its southern part (AvignonMarseille) it is no more a valley but a delta without sidewalls (Fig. 1). The dynamics of the mistral is therefore more complex.

To show the complexity of the mistral flow, the simulated and observed wind fields on 28 June 2001 at 1100 UTC and at 500 m AGL are shown in Fig. 4. The mistral wind originates from the northern end of the Rhône valley with a cyclonic curvature and extends beyond the southern boundary of the inner domain (Fig. 1). The western boundary of the mistral is defined by a wake trailing downstream of the Massif Central (Jiang et al. 2003). Within this large wake, regions of alternating higher- and lowerwind speed form three secondary wakes (generating secondary PV banners) similar to the structure documented during the MAP experiment in the Po valley (Schär et al. 2003; Flamant et al. 2004). The three narrow wakes form in the lee of Mont Mézenc 

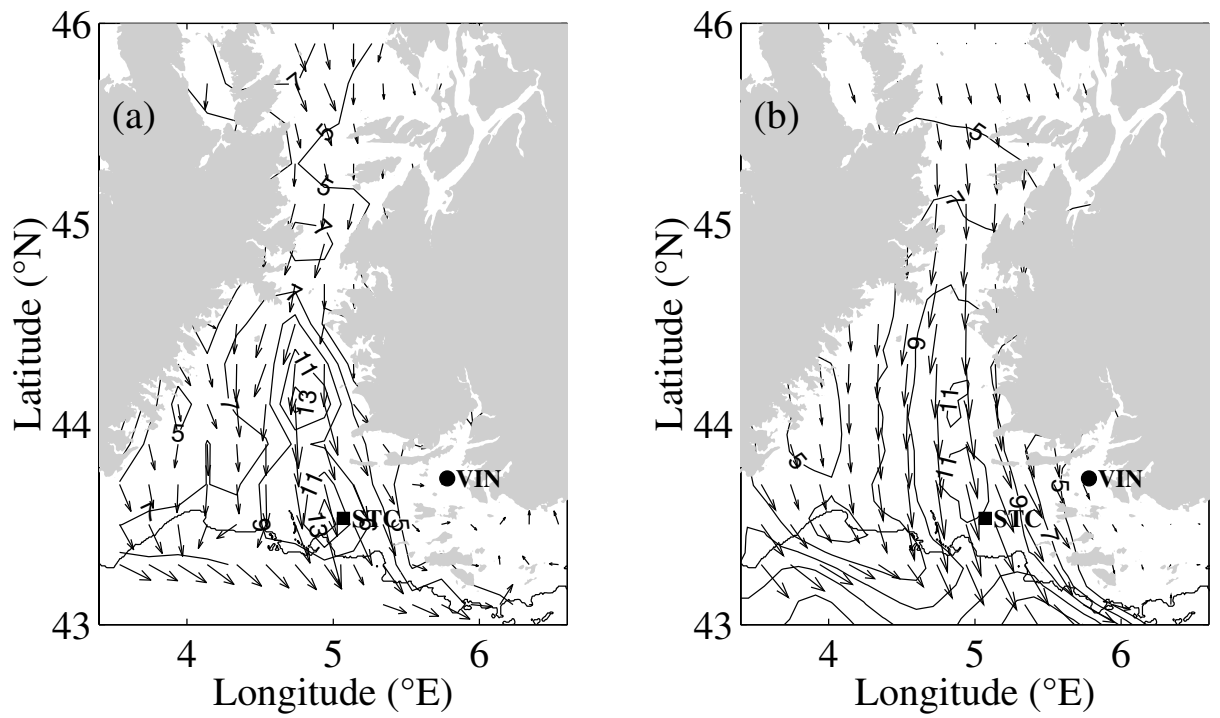

Figure 5. Surface wind field from (a) the operational meteorological station network and (b) MM5 simulations on 28 June 2001 at 1100 UTC. The topography mask corresponds to topographical elements higher than $500 \mathrm{~m}$ ASL. The arrows indicate the wind direction and their scale indicate the intensity. The isolines indicate the wind strength. Contour interval is $2 \mathrm{~m} \mathrm{~s}^{-1}$ from 5 to $17 \mathrm{~m} \mathrm{~s}^{-1}$.

(a peak culminating at $1754 \mathrm{~m}$ in the Vivarais ridge, corresponding to the northernmost wake, see the filled black square), Mont Lozère (1702 m, corresponding to the middle wake, see the filled black circle) and Mont Aigoual (1565 $\mathrm{m}$ in the Cévennes ridge, corresponding to the southernmost wake, see the filled black diamond). To the east, a sharp shear line separates the mistral wind from mountain wakes trailing from the western Alps. The high-wind zone is more than $300 \mathrm{~km}$ long and about $150 \mathrm{~km}$ wide with wind speed over $20 \mathrm{~m} \mathrm{~s}^{-1}$ over Saint Chamas. Figures 4(b) and (c) zoom in on the region documented by the airborne Doppler lidar WIND and compare the simulated (b) and measured (c) wind fields. The overall simulated structure is in good agreement with the observations. Looking in detail, MM5 underestimates the wind speed, and the shear line is too far to the east which implies that, in the inner domain, MM5 does not show the flow reversal to the east of the shear line that is clearly visible in the WIND measurements (Fig. 4(c)). In the larger domain (not shown), flow reversal occurs at about $6.7^{\circ} \mathrm{E}$, that is about $70 \mathrm{~km}$ to the east with respect to the observations. Similar horizontal structure is found in the surface wind field obtained from the operational meteorological station network and displayed in Fig. 5 for 28 June 2001 at 1100 UTC. The surface wind field shows evidence of the two wakes behind the Massif Central and the Alps with flow reversal to the east of the eastern mistral boundary. In Fig. 5, the acceleration of the mistral flow in the gap part of the Rhône valley is visible, with flow deceleration on the eastern flank of the Rhône valley between $44.2^{\circ} \mathrm{N}$ and $44^{\circ} \mathrm{N}$ (i.e. in the delta part of the Rhône valley). This is the location where a hydraulic jump is diagnosed by Pettré (1982) and Corsmeier et al. (2005). The MM5 model does simulate the flow deceleration but it is less pronounced than the observed deceleration $\left(-4 \mathrm{~m} \mathrm{~s}^{-1}\right.$ observed against $-1 \mathrm{~m} \mathrm{~s}^{-1}$ simulated). At the surface, MM5 also reproduces accurately the wind speed but with no flow reversal where it is observed. For instance, Fig. 6 compares the time evolution of the observed and simulated $10 \mathrm{~m}$ wind speed and direction at Vinon (in the sheltered area) and at Saint Chamas (in the core of the mistral jet). At Vinon, despite the 

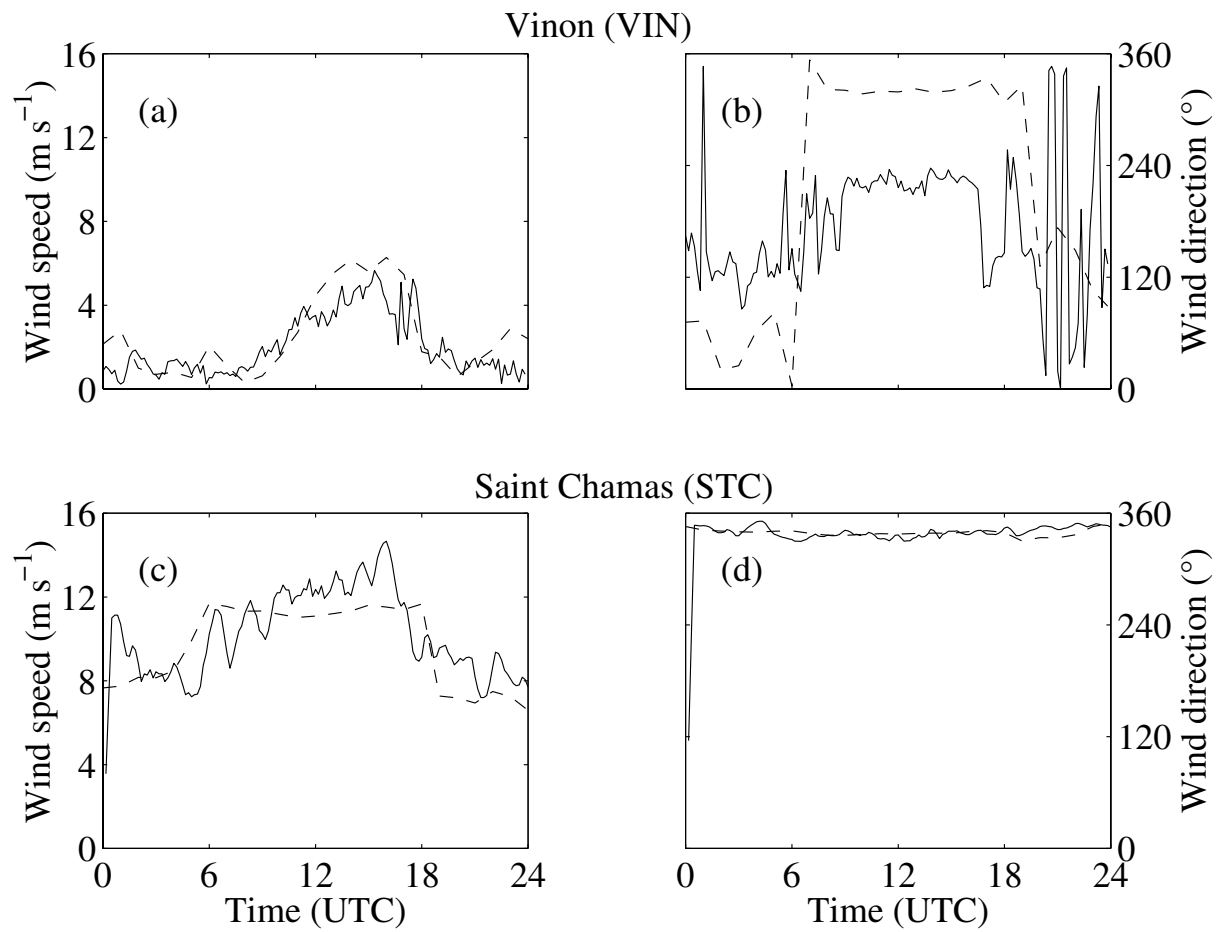

Figure 6. Wind field speed (a) and (c) and direction (b) and (d) as a function of time from the surface station measurements (solid line) and from the MM5 simulations (dashed line). The upper row corresponds to the wind in Vinon and the lower row to the wind at Saint Chamas (see Fig. 1c).

accurate simulation of the wind speed (less than $1 \mathrm{~m} \mathrm{~s}^{-1}$ difference between MM5 and the measurements, at most), there is a clear shift in direction since the simulated wind is from the north-west $\left(320^{\circ}\right)$ whereas the observed wind is from south-west $\left(220^{\circ}\right)$. At Saint Chamas, MM5 performs very well (at most, $1.5 \mathrm{~m} \mathrm{~s}^{-1}$ and $10^{\circ}$ differences for the wind speed and direction, respectively).

In vertical planes, Fig. 7 displays the wind field measured along legs B-A and C-D (see Fig. 1) by the airborne Doppler lidar WIND (Fig. 7(a) and (c)) and the corresponding simulated field (Fig. 7(b) and (d)). Arrows indicate the horizontal wind speed and direction as a function of height, and the superimposed colour map the wind strength. Observations clearly show the north-westerly synoptic wind blowing at about $10 \mathrm{~m} \mathrm{~s}^{-1}$ above about $2 \mathrm{~km} \mathrm{ASL}$. In a $1000 \mathrm{~m}$ deep layer, the mistral flow, confined within the PBL depth and experiencing the Rhône valley constriction, blows parallel to the valley axis with an intensity of about $20 \mathrm{~m} \mathrm{~s}^{-1}$ inland (down to $43.7^{\circ} \mathrm{N}$ ). As the mistral reaches the Rhône valley exit, it decelerates and becomes shallower as the Rhône valley enlarges $\left(13 \mathrm{~m} \mathrm{~s}^{-1}\right.$ between $43.2^{\circ} \mathrm{N}$ and $\left.43.7^{\circ} \mathrm{N}\right)$ which is consistent with a supercritical flow (Drobinski et al. 2001b). Along this leg, the MM5 model does not reproduce this deceleration. Over the Mediterranean (to the south of latitude $43.2^{\circ} \mathrm{N}$ ), the mistral accelerates. The horizontal wind field shown in Fig. 4(a) provides evidence of horizontal convergence over the sea (as the tramontane and mistral flows merge) which results in an acceleration of the mistral flow over the sea. Other processes such as the change of dynamical roughness associated with the land-sea transition could be responsible for accelerating the mistral flow over the sea. 

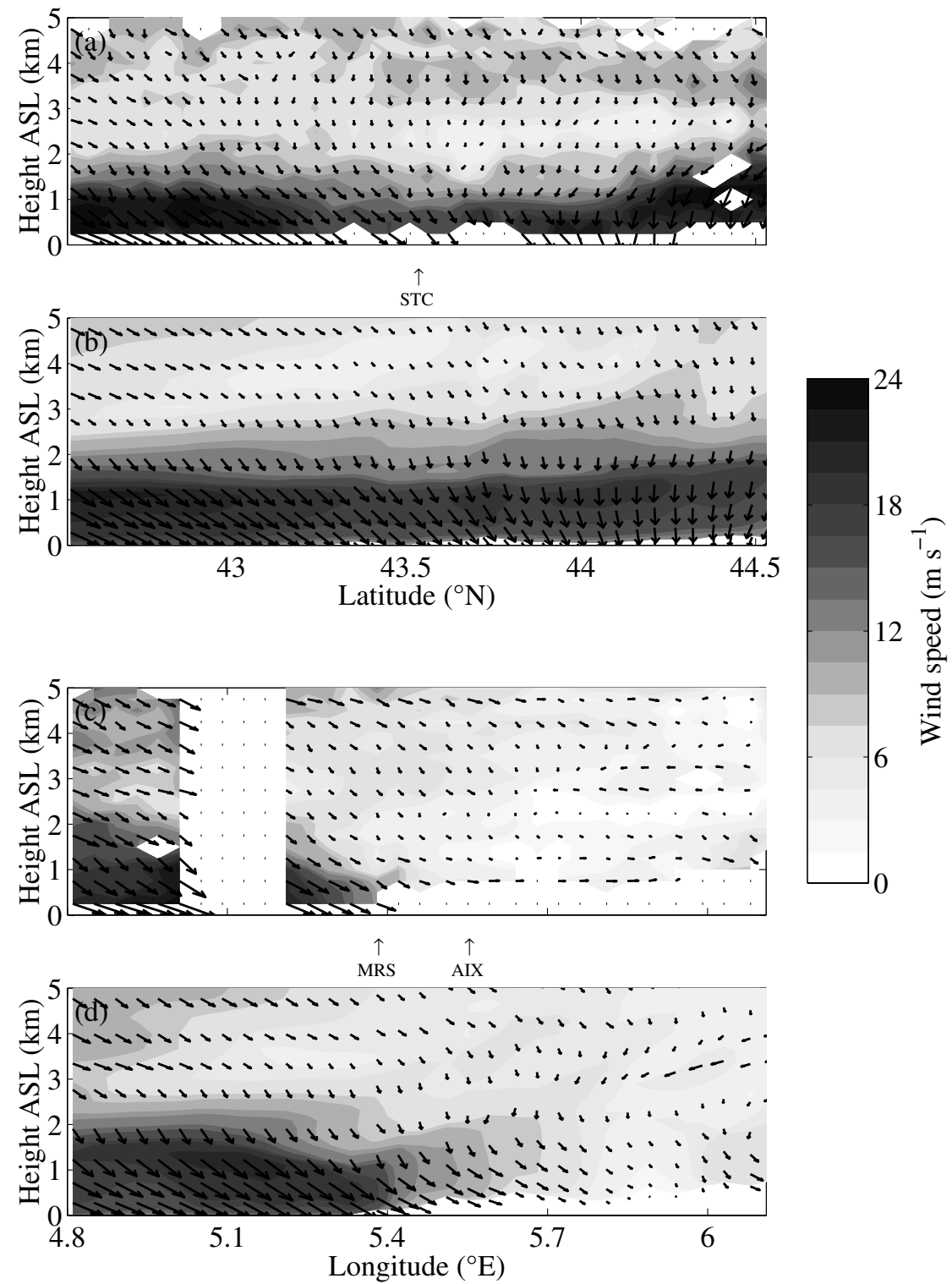

Figure 7. Horizontal wind field along legs B-A (a) and (b), and C-D (c) and (d) shown in Fig. 1. (a) and (c) correspond to the measurements by the airborne Doppler lidar WIND and (b) and (d) to the simulations. The vertical arrows below (a) and (c) indicate the locations of Saint Chamas (STC), Aix en Provence (AIX) and Marseille (MRS).

Along leg C-D, Fig. 7(c) and (d) evidences the core of the mistral and the location of the zone of maximum shear that separates the mistral flow from the sheltered zone (at $5.4^{\circ} \mathrm{E}$ longitude, near Marseille). It also illustrates the large horizontal inhomogeneity at very small scales. In fact, Aix en Provence is located at about $30 \mathrm{~km}$ to the north of Marseille and $30 \mathrm{~km}$ to the north-east of Saint Chamas. Figure 7 shows that the mistral is a maximum over land near Saint Chamas and that the mistral flow weakens over Marseille since Marseille is located near the mistral eastern boundary. Over Marseille and Saint Chamas, there is a good agreement between the simulations and the observations. 


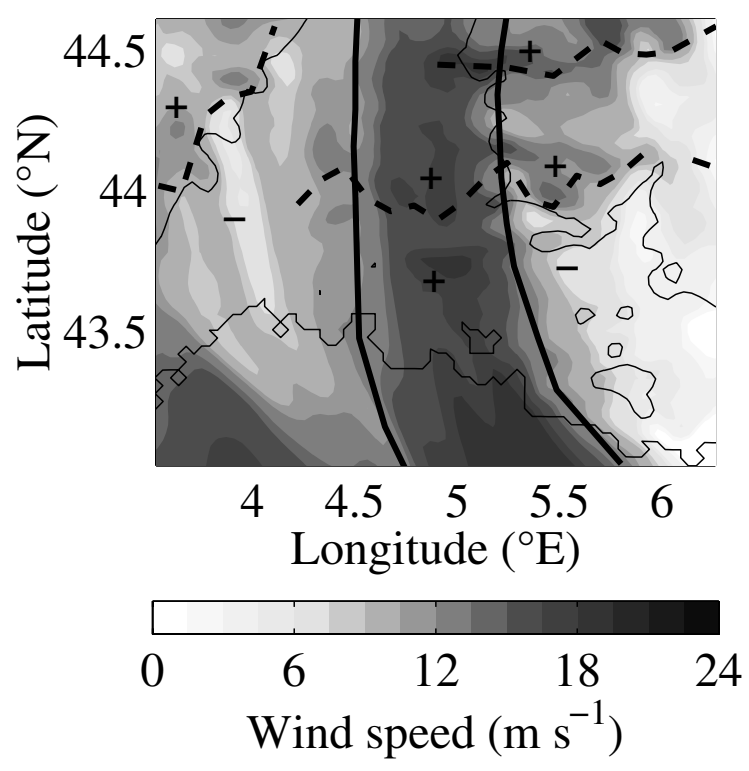

Figure 8. Simulated $500 \mathrm{~m}$ AGL wind speed over the Rhône valley delta on 28 June 2001 at 1100 UTC. The dashed lines indicate the locations of hydraulic jumps, the solid line shows the eastern and western shear line of the mistral flow. The signs ' + ' and '-' correspond to supercritical flow (i.e. local Froude number greater than 1) and subcritical flow (i.e. local Froude number lower than 1), respectively.

At Aix en Provence, the mistral does not blow anymore since the city is located near the shearline in the sheltered area in the lee of the western Alps whereas in the simulations, the mistral still blows over it. The MM5 model is here unable to capture this small-scale variability.

\section{(b) Flow regime analysis}

Investigating the flow regime at the scale of the Rhône valley delta, Fig. 8 shows the simulated $500 \mathrm{~m}$ AGL wind speed over the Rhône valley delta with light/dark colours indicating slow/fast flow. In the present case, the flow impinging on the Alpine range and the Massif Central becomes supercritical all along the ridge line (i.e. the local Froude number greater than unity), including the Rhône valley, and continues to accelerate in the lee regions until a hydraulic jump occurs (transition from supercritical to subcritical regime, i.e. the local Froude number becomes lower than unity after the hydraulic jump). Hydraulic jumps correspond to a steepening gravity wave, coincident with wind speed deceleration and turbulent kinetic energy maximum (not shown), which are visible in Fig. 9 in meridional cross-sections of potential temperature cutting through Mont Lozère (Massif Central), the Rhône valley and the western French Alps (with Montagne Sainte Victoire at about $43.3^{\circ} \mathrm{N}$, Montagne de Lure at about $44.2^{\circ} \mathrm{N}$ and the Devoluy massif north of $44.4^{\circ} \mathrm{N}$ ).

The hydraulic jumps in the lee of the Massif Central and the Alpine ridge lead to the formation of strong wakes behind and close to these peaks. The connection between mountain wakes and hydraulic jumps has been noticed by previous studies (e.g. Smith et al. 1997; Rotunno et al. 1999). The location of hydraulic jump occurrences are displayed by dashed lines in Fig. 8 while the mistral shear line locations are indicated by solid lines. Figure 8 shows that in the lee of the Massif Central, the downslope wind accelerates from 7 (upstream of Mont Aigoual, Mont Lozère and Mont Mézenc) 

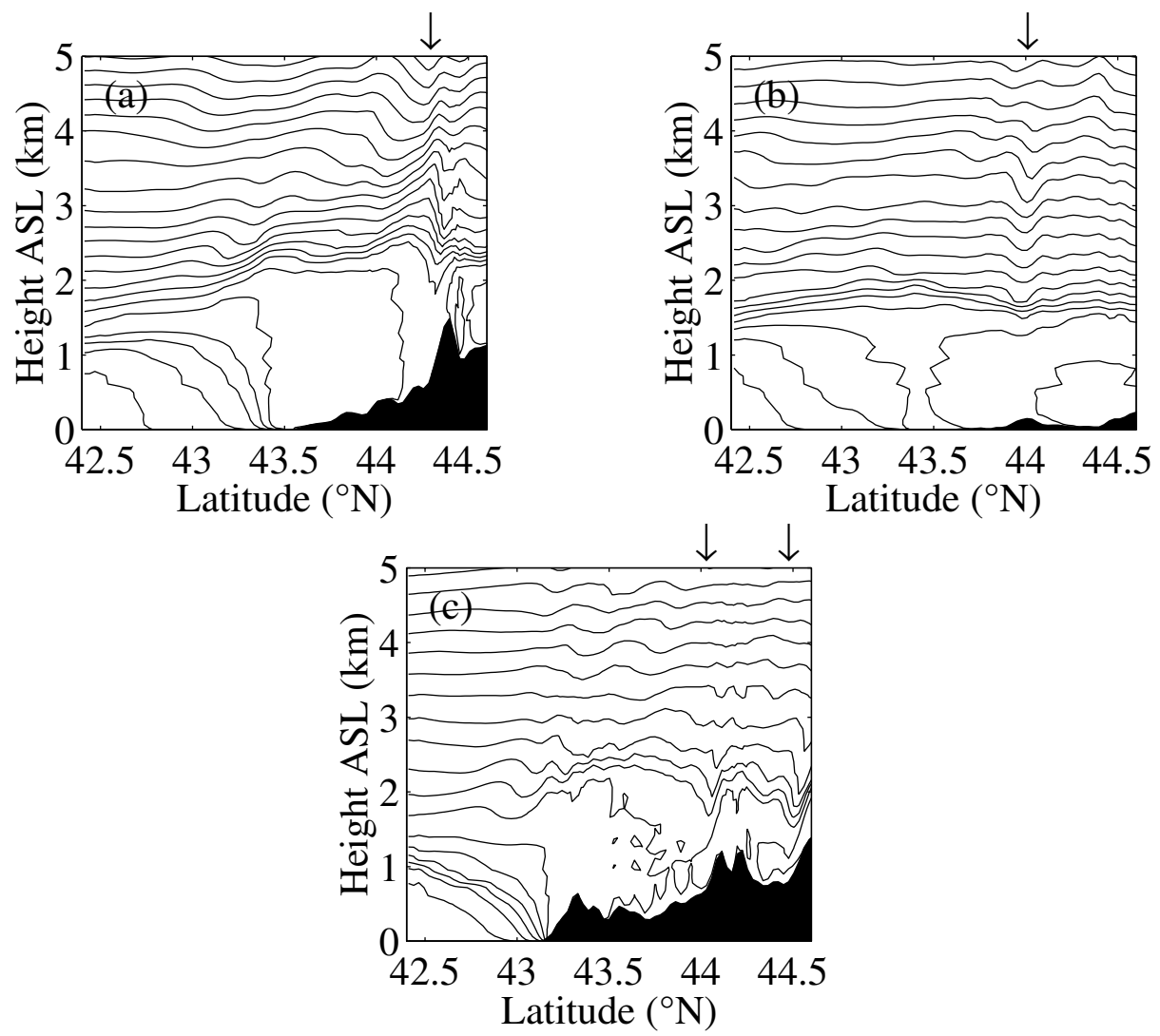

Figure 9. Meridional cross sections of simulated isentropes on 28 June 2001 at 1100 UTC (a) downstream of the Massif Central, (b) along the Rhône valley and (c) in the lee of the Alps. The arrows indicate the hydraulic jump locations.

to $10 \mathrm{~m} \mathrm{~s}^{-1}$ (at the foothills of Mont Aigoual, Mont Lozère and Mont Mézenc) and, associated with the hydraulic jumps, the low-level wind speed then decreases from 10 to $5 \mathrm{~m} \mathrm{~s}^{-1}$. Jiang et al. (2003) found that a stationary cloud-clearing line was located over the lee of the Massif Central and was associated with the acceleration of the mistral wind. They found that the mistral wind was separated from the tramontane by the Mont Lozère wake created by a hydraulic jump over the lee of Mont Lozère. In their mistral cases, the persistent and narrow Mont Lozère wake extended more than $100 \mathrm{~km}$ downstream with banner clouds above it, probably due to the deeper turbulent PBL in the wake associated with the jump, and turbulent mixing of moisture from the sea surface. In our case, surface stations measuring radiative fluxes and satellite pictures did not reveal any cloud formation that could evidence gravity wave breaking. Figure 8 shows that in the lee of the Alps, the hydraulic jump is associated with a low-level wind speed decrease of $-10 \mathrm{~m} \mathrm{~s}^{-1}$, from 15 to less than $5 \mathrm{~m} \mathrm{~s}^{-1}$. In the western Alps wake, Figs. 8 and 9(c) display two consecutive hydraulic jumps due to the several peaks (the Devoluy massif and Montagne de Lure) that perturb the downslope flow. The mistral jet takes a cyclonic curvature at the exit of the Rhône valley due to the Genoa cyclone, which makes its structure asymmetrical between the Massif Central and the Alps (see Fig. 4), contrary to the observations and numerical simulations of flows exiting gaps and valleys (Pan and Smith 1999; Schär et al. 2003; Flamant et al. 2004). 
According to Jiang et al. (2003), the origin of the western Alps wake is rather complicated. They suggest that possible mechanisms include dissipation due to hydraulic jumps and PBL turbulence. In this study, the observations and simulations suggest a combined wall separation/gravity wave breaking mechanism to explain the western Alps wake (wall separation meaning that the flow detaches from the sidewall of the Rhône valley). The flow regime for left-right symmetric shallow-water flow past circular topography was discussed by Schär and Smith (1993). The flow regime depends on the upstream Froude number $F r=U / \sqrt{g^{\prime} H}$ and the dimensionless mountain height $M=h / H$, where $h$ is the mountain height. In our case, $F r=0.58$ and $M=1.1$ (with $H \simeq 2.3 \mathrm{~km}, g^{\prime} \simeq 1.3 \times 10^{-1} \mathrm{~m} \mathrm{~s}^{-2}, U \simeq 10 \mathrm{~m} \mathrm{~s}^{-1}$ and $h=2.5 \mathrm{~km}$ ). In the Schär and Smith regime diagram the present case is at the boundary between regimes IIb and III, which correspond to a wake regime associated with the formation of a hydraulic jump (their regime IIb, see their Fig. 3) and to one characterized by the inability of the flow to go over the hilltop and, correspondingly, the presence of a stagnation point on the windward slope and the occurrence of flow separation (their regime III). The two regimes include reverse flow in the wake. The large value of the dimensionless mountain height $N h / U \simeq 2$, computed using the measurements of the radiosonde launched from Lyon (Fig. 3), means that the impinging airstream is diverted around the flanks of the mountain with a stagnation point on the windward side. Moreover, Figs. 4 and 5 clearly show the separation of the mistral flow from the eastern flank of the Rhône valley at about $44^{\circ} \mathrm{N}$ and the reverse flow in the wake. In Schär and Smith (1993), the separation point is associated with a 'flank-shock' also called oblique hydraulic jump, meaning that the downstream Froude number is supercritical. In fact, in the Rhône valley, Fig. 9(b) shows that the hydraulic jump is comparatively smoother (no strong steepening wave or sharp PBL depth change) than those found downstream of mountain peaks, and does not correspond to a return to a subcritical regime (Fig. 8). This jump is still associated with flow deceleration, as discussed in section 4(a) (from 20 to $10 \mathrm{~m} \mathrm{~s}^{-1}$ at $500 \mathrm{~m} \mathrm{AGL}$ and from 12 to $8 \mathrm{~m} \mathrm{~s}^{-1}$ at the surface) and shown in Figs. 5 and 8 . Figure 8 also shows (dashed line) the hydraulic jump occurring perpendicularly to the eastern valley sidewall at the precise location of the mistral flow separation $\left(44^{\circ} \mathrm{N}\right)$. However, the present situation is similar to the transient regime of the Schär and Smith (1993) simulations (their Figs. 8, 9 and 10(b)). For a steady-state separation point, the flow on both sides of the shear line after the flank-shock should be subcritical (Figs. 7 and 10(a) in Schär and Smith 1993), which is not the case for the mistral flow which is obviously supercritical downstream of the flank-shock. Various reasons can be invoked for this:

- The mistral flow is transient. Indeed, Flamant (2003) and Guénard et al. (2005) investigated experimentally very fast transitions (on a scale of a few hours) of the mistral flow structure. However, in our case, and despite the diurnal evolution of the mistral, the time for the low-level flow to adjust to the local pressure field is substantially shorter than the time-scale of large-scale flow variability, so that the steady-state flow assumption should be met (see Figs. 3 and 6).

- The surface roughness change, due to the absence of mountain peaks and to the presence of the Mediterranean (and convergence with the tramontane) downstream of the flank-shock, may accelerate the mistral flow which may become supercritical (see Koffi et al. 1993 and Drobinski et al. 2001a for discussion on a similar feature during a tramontane event).

The detailed nature of the mistral flow downstream of the in-valley jump (flankshock) is still to be investigated. 


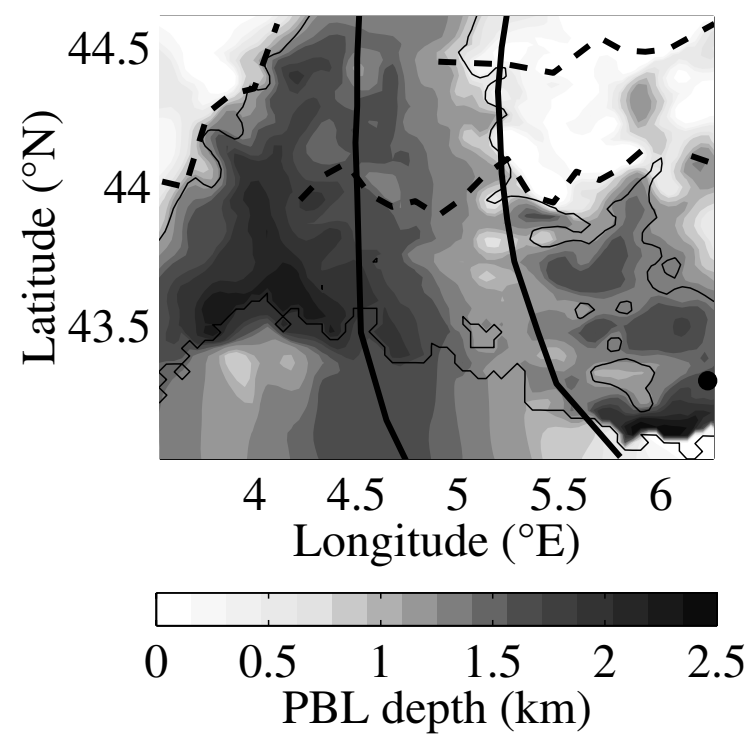

Figure 10. Simulated PBL depth over the Rhône valley delta on 28 June 2001 at 1100 UTC. The dashed lines indicate the locations of hydraulic jumps, the solid line shows the eastern and western shear line of the mistral flow. The filled black circle indicates the location of the pénéplaine du Luc.

\section{IMPACT OF THE JET/WAKE STRUCTURE ON THE PBL HORIZONTAL VARIABILITY}

The large horizontal variability of low-level atmospheric flow at the exit of the Rhône valley, with alternating regions of jets and wakes, impacts on the local structure of the PBL and the associated thermodynamics. Indeed, Fig. 10 displays the simulated PBL depth over the Rhône valley delta on 28 June 2001 at 1100 UTC. It shows that downstream of hydraulic jumps, the PBL depth sharply increases (Drobinski et al. 2001b). In the Massif Central and western Alps wakes, the continental PBL is deeper than in the mistral flow, which is consistent with a subcritical regime associated with enhanced turbulent mixing. In the Massif Central wake, the average PBL depth is about 1.8-2 km. The region of highest PBL depth downstream of the Massif Central corresponds to the Mont Lozère wake. The supercritical airflow descending the Massif Central slopes and transitioning to subcritical flow increases the near-surface air temperature due to the föhn effect, as shown in Fig. 11, which displays the measured and simulated surface temperature field on 28 June 2001 at 1100 UTC.

Within the mistral flow, there is a large zonal variability of the PBL depth, which decreases from about $1.7 \mathrm{~km}$ near its western boundary (see radiosonde over Nîmes in Fig. 3(f)) to about $1 \mathrm{~km}$ along its eastern boundary as shown in Fig. 12(a) which displays the PBL depth retrieved from the lidar signals (solid line) and from the MM5 simulations (dashed line) in the mistral flow near its eastern edge along leg $\mathrm{B}-\mathrm{A}$. The agreement between the observed and simulated PBL depths is very good with an average bias of about $200 \mathrm{~m}$. The lower PBL depth in the mistral flow is due to the cold air advection which stabilizes the upper PBL and decreases the potential inversion height. The impact of enhanced convection due to cold air advection, therefore increasing the surface heat fluxes, is partly damped by the strong wind shear.

Compared to the PBL structure in the Massif Central wake, similar thermodynamics drives the PBL structure in the lee of the western Alps: the PBL is deeper in the western Alps wake because of the strong hydraulic jumps occurring along the mountain slopes, 

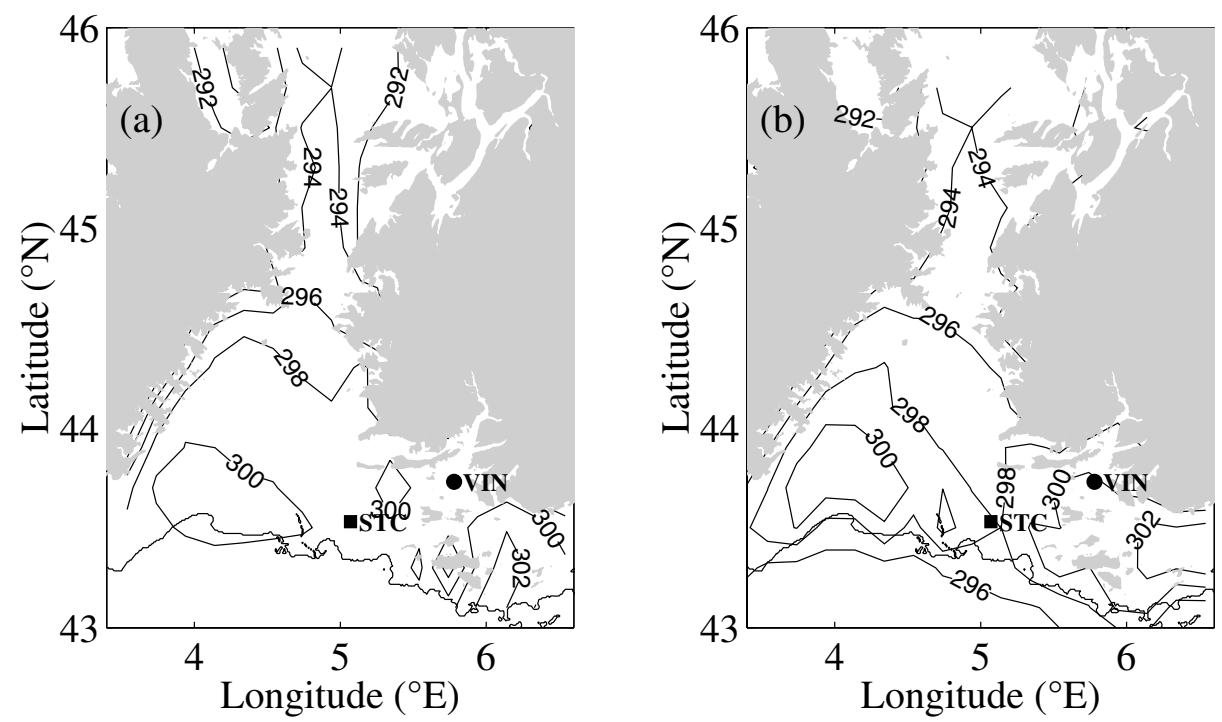

Figure 11. Surface temperature field from (a) the operational meteorological station network and (b) MM5 simulations on 28 June 2001 at 1100 UTC. The topography mask corresponds to topographical elements higher than $500 \mathrm{~m}$ ASL. The isolines indicate the temperature. Contour interval is $2 \mathrm{~K}$ from 290 to $304 \mathrm{~K}$.
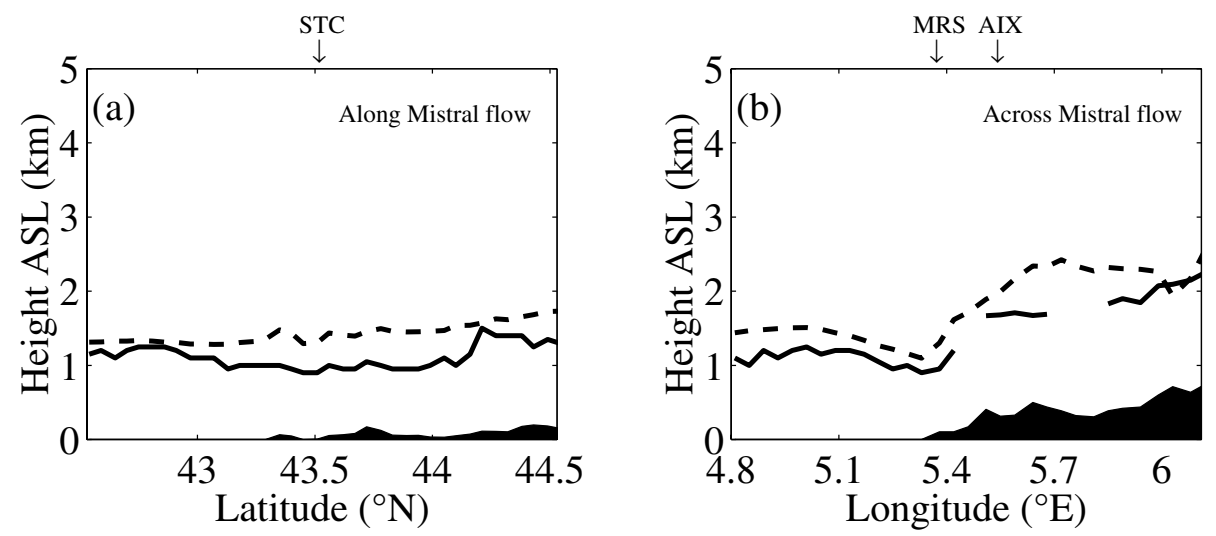

Figure 12. PBL depth retrieved from the WIND measurements (thick solid line) and from the MM5 simulations on 28 June 2001 at 1100 UTC (thick dashed line) along (a) leg B-A and (b) leg C-D. The topography is represented by the black area.

also leading to the surface temperature increase as shown in Fig. 11. In the lee of the western Alps, substantial heating occurs in the pénéplaine du Luc, which is correctly simulated by MM5 (302 K). It is an area located at about $6.23^{\circ} \mathrm{E}$ and $43.3^{\circ} \mathrm{N}$ (see filled black circle in Fig. 10) and surrounded by hills culminating at about $800 \mathrm{~m}$ (the massif des Maures to the south, the massif de l'Estérel to the east and the Provence mountains to the north and to the west) which prevent air ventilation and enhance convection (Galzi 1952). The deepening of the PBL depth between the two sides of the mistral eastern shear line is much sharper than on the mistral western shear line (Fig. 10). Indeed, Fig. 12(b), which displays the PBL depth across the mistral flow (leg C-D), shows that the PBL depth increases between $1 \mathrm{~km}$ in the mistral flow along its eastern edge up to 
$1.6 \mathrm{~km}$ in the western Alps wake over a horizontal distance of about $10 \mathrm{~km}$. This sharp PBL depth gradient is probably due to the wall separation on the eastern flank of the Rhône valley: indeed the eastern shear line separates the mistral flow from a flow almost at rest (see for instance Figs. 4 and 5), and the Schär and Smith (1993) simulations clearly show a strong variation of fluid depth across the shear line (see their Figs. 9(a) and $10(b))$.

The PBL structure over the Mediterranean differs significantly from that above land: the marine PBL is shallower than the continental PBL. Indeed, the air temperature is warmer than the sea surface temperature and the surface heat fluxes are slightly negative over the sea (between -50 and $0 \mathrm{~W} \mathrm{~m}^{-2}$ ) (not shown). Figure 12(a) shows the PBL depth along the mistral flow over land and over the sea (the coastline is located at about $43.5^{\circ} \mathrm{N}$ ). Both the measurements and the simulations of the PBL depth do not reveal large variability. Over the sea, the main source of turbulence within the marine PBL is mechanical (wind shear) since there is no convective activity (contrary to the spring mistral case investigated by Flamant 2003). Over the sea, the MM5 model gives a friction velocity $u_{\star} \simeq 0.6 \mathrm{~m} \mathrm{~s}^{-1}$ in the mistral flow. In a stably stratified PBL, an estimation of the PBL depth is $C u_{\star}^{3 / 2}$ with $C=2400 \mathrm{~m}^{-1 / 2} \mathrm{~s}^{3 / 2}$ (Ventkarman 1980). This expression gives a marine PBL depth of $1.1 \mathrm{~km}$, which is in good agreement with the observations and the simulations. Downstream of the Massif Central and western Alps wakes, the PBL depth displays a large variability perpendicular to the coastline, with a deep continental PBL (about $2 \mathrm{~km}$ downstream of the Massif Central, about $1.6 \mathrm{~km}$ downstream of the western Alps and about $2 \mathrm{~km}$ over the pénéplaine du Luc) and a shallow marine PBL (about $0.7 \mathrm{~km}$ deep downstream of the Massif Central and about $0.4 \mathrm{~km}$ downstream of the western Alps). The absence of convection and strong shear prevents PBL development in the sheltered regions downstream of the Massif Central and the Alps.

\section{CONCLUSIONS}

We have investigated experimentally, numerically and theoretically the mistral flow structure at the exit of the Rhône valley and more specifically the mechanism of wake formation downstream of the Massif Central and the Alps, and the impact on PBL inhomogeneity.

This study shows that the flow impinging on the Alpine range and the Massif Central becomes supercritical all along the ridge line, including the Rhône valley, and continues to accelerate in the lee regions until a hydraulic jump occurs. This leads to the formation of wakes behind and close to the peaks. In this study, the observations and simulations suggest that the western Alps wake originates from a combined wall separation/gravity wave breaking mechanism. Indeed, it is shown that in addition to the flow descending the western Alps slopes and experiencing a strong hydraulic jump, the point where the mistral flow separates from the eastern flank of the Rhône valley located at about $44^{\circ} \mathrm{N}$ is associated with a 'flank-shock' which is an oblique hydraulic jump (i.e. the downstream Froude number is supercritical). It is exactly at this location that Pettré (1982) and Corsmeier et al. (2005) diagnosed a hydraulic jump using reducedgravity shallow-water theory. The present study clearly advocates a more 3D mechanism involving 'classical' hydraulic jumps along the Massif Central and the western Alps slopes and an 'oblique' hydraulic jump as suggested by Schär and Smith (1993) within the Rhône valley. Wake formation in the lee of the Alps and the Massif Central causes large inhomogeneity of the PBL with differences between land and sea. In the Massif Central and western Alps wakes, the continental PBL is deeper (about $1.8 \mathrm{~km}$ ) than in 
the mistral flow $(1 \mathrm{~km})$, which is consistent with a subcritical regime associated with enhanced turbulent mixing. The supercritical air flow, descending the Massif Central and Alps slopes and transitioning to subcritical flow, increases the near-surface air temperature due to the föhn effect. Over the Mediterranean, the surface heat fluxes are slightly negative and in the wakes of the Massif Central and the Alps, the absence of convection but also of strong winds prevent PBL development over the sea, and its depth does not exceed $0.5 \mathrm{~km}$. In the mistral flow, the main source of PBL turbulence is mechanical (wind shear), and the PBL depth does not vary over land $(1 \mathrm{~km})$.

The occurrence of the hydraulic jump at the same location when using the reducedgravity shallow-water theory and when analysing the 3D flow is still to be analysed: one may suggest a purely coincidental occurrence or the result of a combined occurrence of an 'oblique' jump caused by wall separation and a more classical jump caused by valley constriction. The detailed nature of the 'oblique' hydraulic jump (transient or steady) and of the actual occurrence of a gap-induced hydraulic jump will be addressed, probably using idealized simulations.

\section{ACKNOWLEDGEMENTS}

This work was conducted at Service d'Aéronomie and Laboratoire de Météorologie Dynamique of the Institut Pierre Simon Laplace. The authors would like to thank B. Campistron, U. Corsmeier, F. Lohou and R. Vautard for fruitful discussion; M. C. Lanceau for help in collecting the referenced papers; and B. Cros and P. Durand for the coordination of the experiment. The flights of the DLR Falcon were funded partly by the CAATER (Co-ordinated Access to Aircraft for Transnational Environmental Research) program of the European Commission. We would also like to thank E. Nagel (DLR) for assistance in operation of the WIND system, the pilots of the DLR flight facility R. Welser and M. Hinterwaldner, the Falcon technician and the great support of the CAATER facilitator A. Giez (DLR). In the framework of the French programmes PNCA and PRIMEQUAL-PREDIT, ESCOMPTE was performed thanks to funding from the Ministère de l'Écologie et du Développement Durable (MEDD), the Agence de l'Environnement et de la Maîtrise de l'Énergie (ADEME), the Institut National des Sciences de l'Univers (INSU), Météo-France, the Institut National de l'Environnement Industriel et des Risques (INERIS), the German funding agency (BMBF), the Institute for Meteorology and Climate Research (IMK- Karlsruhe), the Joint Research Center (JRC-Ispra), the Swiss Federal Institute of Technology (EPFL-Lausanne), the Centre National d'Études Spatiales (CNES), Électricité de France (EDF), the air quality agencies Airmaraix and Airfobep, the cities of Marseilles and Aix-en-Provence, and the county council of the Bouches-du-Rhône. We particularly thank M. P. Lefebvre who played a crucial role in the delicate organization of the flights.

\section{REFERENCES}

Aebischer, U. and Schär, C.

Bastin, S. and Drobinski, P.

Bastin, S., Drobinski, P., Dabas, A. M., Delville, P., Reitebuch, O. and Werner, C.

Bordeuil, C., Barbia, A. and Comte, $\mathrm{P}$.
Low-level potential vorticity and cyclogenesis to the lee of the Alps. J. Atmos. Sci., 55, 186-207

Temperature and wind velocity oscillations along a gentle slope during sea-breeze events. Boundary-Layer Meteorol., in press

Impact of the Rhône and Durance valleys on sea-breeze circulation in the Marseille area. Atmos. Res., in press

'Vent du nord-ouest et mistral à Marseille de 1882 à 1970'. Monographie 88 de la Météorologie Nationale 
Bougeault, P., Binder, P., Buzzi, A., Dirks, R., Houze, R.,

Kuettner, J., Smith, R. B., Steinacker, R. and Volkert, $\mathrm{H}$.

Caccia, J.-L., Guénard, V., Bénech, B., Campistron, B. and Drobinski, P.

Campins, J., Genovés, A. Jansà, A. Guijarro, J. A. and Ramis, C.

Caya, D. and Zawadzki, I.

Corsmeier, U., Behrendt, R., Drobinski, P. and Kottmeier, C.

Cros, B., Durand, P., Cachier, H., Drobinski, P., Fréjafon, E., Kottmeier, C., Perros, P. E., Peuch, V.-H., Ponche, J.-L., Robin, D., Saïd, F., Toupance, G. and Wortham, $\mathrm{H}$.

Drobinski, P., Flamant, C., Dusek, J., Flamant, P. H. and Pelon, J.

Drobinski, P., Dusek, J. and Flamant, C.

Drobinski, P., Haeberli, C., Richard, E., Lothon, M., Dabas, A. M., Flamant, P. H., Furger, M. and Steinacker, R.

Eliassen, A. and Palm, E.

Flamant, C.

Flamant, C., Drobinski, P.,

Nance, L., Banta, R. M.,

Darby, L., Dusek, J.,

Hardesty, R. M., Pelon, J. and Richard, E.

Flamant, C., Richard, E., Schär, C., Rotunno, R., Nance, L., Sprenger, M. and Benoit, R.

Galzi, L.

Georgelin, M. and Richard, E.

Gerbier, N. and Berenger, M.

Grell, G. A.

Grell, G. A., Dudhia, J. and Stauffer, D. R.

Guénard, V., Drobinski, P., Caccia, J.-L., Campistron, B. and Bénech, B.

Guo, Y.-R. and Chen, S.

Hong, S.-Y. and Pan, H.-L.

Jackson, P. L. and Steyn, D. G.

1994

Jansá, A.

1987

Jiang, Q., Smith, R. B. and Doyle, J. D.
The MAP special observing period. Bull. Am. Meteorol. Soc., 82, $433-462$

2005 Vertical velocity and turbulence aspects during Mistral events as observed by UHF wind profilers. Ann. Geophys., in press

A catalogue and a classification of surface cyclones for the western Mediterranean. Int. J. Climatol., 20, 969-984

VAD analysis of nonlinear wind fields. J. Atmos. Oceanic Technol., 9, 575-587

2005 The Mistral and its effect on air pollution transport and vertical mixing. Atmos. Res., in press

The ESCOMPTE program: an overview. Atmos. Res., 69, 241-279

2001a Observational evidence and modelling of an internal hydraulic jump at the atmospheric boundary-layer top during a Tramontane event. Boundary-Layer Meteorol., 98, 497-515

2001b Diagnostics of hydraulic jump and gap flow in stratified flows over topography. Boundary-Layer Meteorol., 98, 475-495

2003 Scale interaction processes during the MAP IOP 12 south foehn event in the Rhine valley. Q. J. R. Meteorol. Soc., 129, 729753

1960 On the transfer of energy in stationary mountain waves. Geophys. Publ., 22, 1-23

2003 Alpine lee cyclogenesis influence on air-sea heat exchanges and marine atmospheric boundary layer thermodynamics over the western Mediterranean during a Tramontane/Mistral event. J. Geophys. Res., 108(C2), FET 5-1, 5-24

2002 Gap flow in an Alpine valley during a shallow south foehn event: observations, numerical simulations and hydraulic analog. Q. J. R. Meteorol. Soc., 128, 1173-1210

The wake south of the Alps: Dynamics and structure of the leeside flow and secondary potential vorticity banners. $Q$. J. $R$. Meteorol. Soc., 130, 1275-1303

1952 Contribution à l'étude du mistral. La Météorologie, 13, 7-24

1996 Numerical simulation of flow diversion around the Pyrenees: a tramontana case study. Mon. Weather Rev., 124, 687-700

1961 Experimental studies of lee waves in the French Alps. Q. J. R. Meteorol. Soc., 87, 13-23

1993 Prognostic evaluation of assumptions used by cumulus parametrizations. Mon. Weather Rev., 121, 764-787

1995 'A description of the fifth-generation Penn State/NCAR mesoscale model (MM5)'. NCAR Technical Note, NCAR/TN398+STR.

2005 Experimental investigation of the mesoscale dynamics of the Mistral. Boundary-Layer Meteorol., in press

'Terrain and land use for the fifth-generation Penn State/NCAR mesoscale modeling system (MM5)'. NCAR Technical Note, NCAR/TN-397+IA.

Nonlocal boundary layer vertical diffusion in a medium-range forecast model. Mon. Weather Rev., 124, 2322-2339

Gap winds in a fjord. Part II: Hydraulic analogue. Mon. Weather Rev., 122, 2666-2676

Distribution of the mistral: A satellite observation. Meteorol. Atmos. Phys., 36, 201-214

2003 The nature of the mistral: Observations and modeling of two MAP events. Q. J. R. Meteorol. Soc., 129, 857-876 
Koffi, E., Georgelin, M., Bénech, B. 1993 and Richard, E.

Liu, M., Westphal, D. L., Holt, T. R. 2000 and $\mathrm{Xu}, \mathrm{Q}$.

Mass, C., Businger, S., Albright, M. 1995 and Tucker, Z. A.

Mayençon, R.

Millot, C.

Mlawer, E. J., Taubman, S. J., Brown, P. D., Iacono, M. J. and Clough, S. A.

Orieux, A., and Pouget, E.

Pan, F., and Smith, R. B.

Pettré, P.

Pierrehumbert, R. T. and Wyman, B.

Reisner, J., Rasmussen, R. M. and Bruintjes, R. T.

Reitebuch, O., Volkert, H., Werner, C., Dabas, A., Delville, P., Drobinski, P., Flamant, P. H. and Richard, E. Rhein, $\mathrm{M}$.

Rotunno, R., Grubišić, V. and Smolarkiewicz, P. K.

Schär, C. and Durran, D. R.

Schär, C. and Smith, R. B.

Schär, C., Sprenger, M., Luthi, D., Jiang, Q., Smith, R. B. and Benoit, R.

Schott, F., Visbeck, M., Send, U., Fischer, J., Stramma, L. and Desaubies, Y.

Scialom, G. and Lemaître, Y.

Smith, R. B., Gleason, A. C., Gluhosky, P. A. and Grubišić, $\mathrm{V}$.

Smolarkiewicz, P. K. and Rotunno, R.

Sprenger, M. and Schär, C.

Trigo, I. F., Davies, T. D. and Bigg, G. R.

Ventkarman, A.

1984

1999

1982

1985

1998

2003

1995

1999

2003

1996

1997

1989

2001

1999
'Étude des mécanismes de formation de la Tramontane'. Pp. 139149 in Atelier de modélisation de l'atmosphère. Toulouse, France

Numerical simulation of a low-level jet over complex terrain in southern Iran. Mon. Weather Rev., 128, 1309-1327

A windstorm in the lee of a gap in a coastal mountain barrier. Mon. Weather Rev., 123, 315-331

Météorologie pratique. Editions Maritimes et d'Outre-Mer, Paris

Wind induced upwellings in the Gulf of Lions. Oceanol. Acta, 2, 261-274

Radiative transfer for inhomogeneous atmospheres: RRTM, a validated correlated-k model for the longwave. J. Geophys. Res., 102(D14), 16663-16682

'Le Mistral: Contribution à l'étude de ses aspects synoptiques et régionaux'. Monographie 5, Direction de la Météorologie

Gap winds and wakes: SAR observations and numerical simulations. J. Atmos. Sci., 56, 905-923

On the problem of violent valley winds. J. Atmos. Sci., 39, 542 554

Upstream effects of mesoscale mountains. J. Atmos. Sci., 42, 977-1003

Explicit forecasting of supercooled liquid water in winter storms using the MM5 mesoscale model. Q. J. R. Meteorol. Soc., 124, 1071-1107

Determination of airflow across the Alpine Ridge by a combination of Doppler lidar, routine radiosounding and numerical simulation. Q. J. R. Meteorol. Soc., 129, 715-727

Deep water formation in the western Mediterranean. J. Geophys. Res., 100(C4), 6943-6959

Vorticity and potential vorticity in mountain wakes. J. Atmos. Sci., 56, 2796-2810

1997 Vortex formation and vortex shedding in continuously stratified flows past isolated topography. J. Atmos. Sci., 54, 534-554

1993 Shallow-water flow past isolated topography. Part I: Vorticity production and wake formation. J. Atmos. Sci., 50, $1373-1400$

Structure and dynamics of an Alpine potential vorticity banner. Q. J. R. Meteorol. Soc., 129, 825-856

Observations of deep convection in the Gulf of Lions, northern Mediterranean, during the winter of 1991-92. J. Phys. Oceanogr., 26, 505-524

1990 A new analysis for the retrieval of the three-dimensional mesoscale wind field from multiple Doppler radars. J. Atmos. Oceanic Technol., 7, 640-665

The wake of St. Vincent. J. Atmos. Sci., 54, 606-623

Low Froude number flow past three-dimensional obstacles. Part I: Baroclinically generated lee vortices. J. Atmos. Sci., 46, $1154-1164$

Rotational aspects of stratified gap flows and shallow foehn. Q. J. R. Meteorol. Soc., 127, 161-188

Objective climatology of cyclones in the Mediterranean region. J. Climate, 12, 1685-1696

1980 Estimating the Monin-Obukhov length in the stable boundary layer for dispersion calculation. Boundary-Layer Meteorol., 17, 28-38 
Werner, C., Flamant, P. H., Reitebuch, O., Köpp, F., Streicher, J., Rahm, S., Nagel, E., Klier, M.,

Hermann, H., Loth, C.,

Delville, P., Drobinski, P., Romand, B., Boitel, C.,

Oh, D., Lopez, M.,

Meissonnier, M., Bruneau, D. and Dabas, A. M.

Wrathall, J. E.
2001 Wind infrared Doppler lidar instrument. Opt. Eng., 40, 115-125

1985 The mistral and forest fires in Provence-Côte d'Azur, Southern France. Weather, 40, 119-124 